the hill sheep industry the transfer of hill land to other uses or the restriction of sheep farming is frequently advocated.

Rarely does this take into account the opportunities for improvement which exist at the biological level or whether modifications to or changes in systems could make sheep production economically viable.

Subsequent papers will present some facts on which it becomes possible to make objective assessments.

Exclusively cattle-based systems have been developed on upland farms and relatively intensive stocking is possible. Cunningham \& Harkins (1967) and Powell (1971) have reported stocking rates of $0.5 \mathrm{ha} /$ cow per annum on upland permanent pastures.

The provision of winter feed is an important aspect of cattle management and this amounts to approximately $40 \%$ of the cost of production of the calf.

Nutrition is of importance not only in relation to performance but it is also of significance in relation to the food resources available and the systems which can be economically developed. The entire field requires urgent investigation.

Calves from cows run on rough grazings are generally small, market demand and consequently price is poor, and frequently growth-rate potential is inadequate.

Generally, the pastoral resources of the hills and uplands are making an important economic contribution to agricultural output. However, it is frequently argued that the problems are essentially sociological.

Given an improvement in the economic viability of hill farming it is possible that many of the so-called sociological arguments might disappear.

Nevertheless there are some aspects of sociological significance - the issues of public access and amenity. Agriculture is an important concomitant of amenity and I do not believe that the development of new systems of animal production in the uplands will in any way militate against properly organized and controlled public access to hill land.

\title{
REFERENCES
}

Anonymous (1971). Annual Review and Determination of Guarantees 1971 [Cmnd 4623]. London: H.M. Stationery Office.

Cunningham, J. M. M. \& Harkins, J. (1967). Scott. Agric. 46, I06.

Duthie, W. B. (1967). Bull. Edinb. Sch. Agric. no. 87.

McCreath, J. (1970). Rep. W. Scotl. agric. Coll. no. I30.

Powell, T. L. (1971). Anim. Prod. 13, 382.

\section{Relationships between energy intake and productivity in hill sheep}

By A. J. F. Russet, Hill Farming Research Organisation, 29 Lauder Road, Edinburgh EH9 $27 Q$

Productivity from hill sheep kept under traditional systems of management is low in comparison with other forms of animal production dependent on pastoral resources, even when allowances are made for differences in herbage production. 
Typical animal outputs are of the order of $20 \mathrm{~kg} \mathrm{lamb}$ per ewe or about $15 \mathrm{~kg}$ lamb per ha, with large variations around these values. There is, however, a growing body of evidence to indicate that native breeds of hill sheep have a relatively high capacity for production, and that this is being limited by the level of nutrition afforded by the traditional free-grazing system of management. A proper understanding of the nutritional limitations to production in the hill environment can come only from a more precise knowledge of the relationships between nutrition and the various components of individual animal productivity.

This paper considers firstly, the annual cycle of energy intake in the traditional system of management, and some of the effects of this on the animal; secondly, the relationships between energy intake and the components of individual animal productivity; and thirdly, the nutritional requirements for new systems aimed at increased levels of animal production from the hill resource.

\section{The annual pattern of energy intake in a free-grazing system}

In the traditional free-grazing system of management the year-round stocking rate is determined by the carrying capacity of the pastures during winter.

Seasonal changes in the quality of herbage ingested by wether sheep set-stocked on a predominantly grass hill pasture are shown in Fig. I (Eadie, 1967). Organic matter digestibility is at a maximum of about 75 in May and June, falling to 70 in

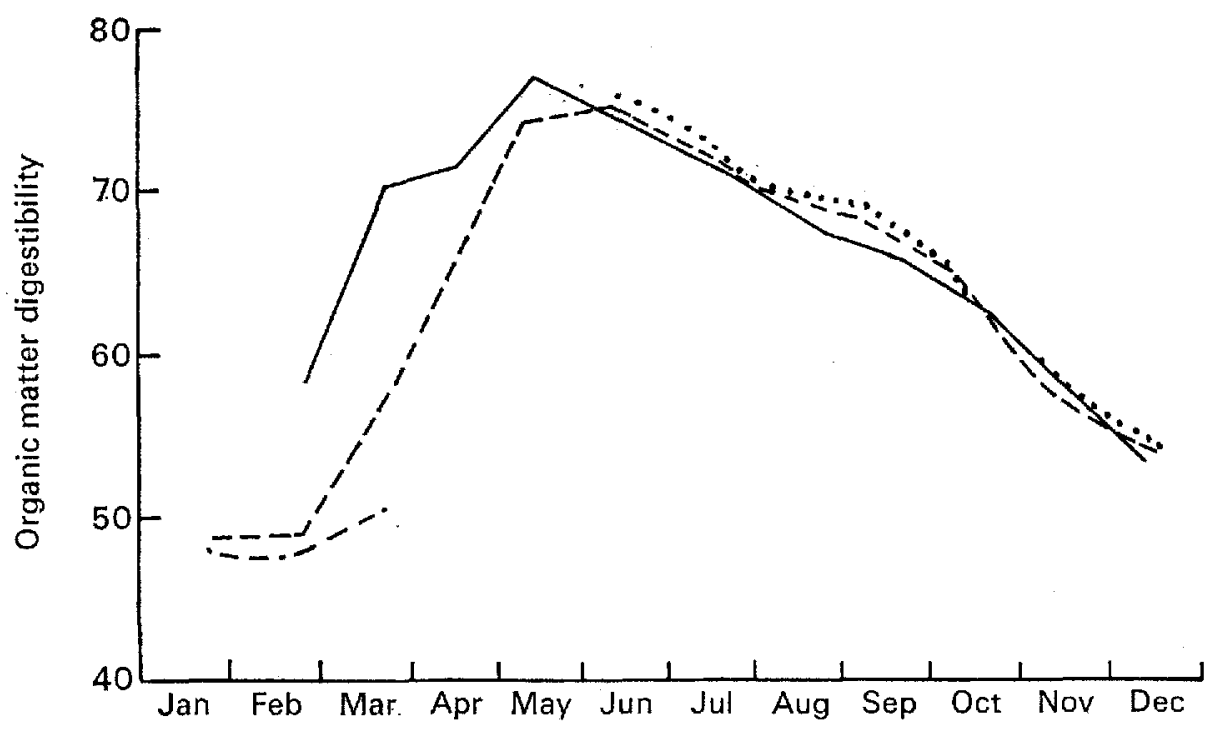

Fig. I. Seasonal changes in digestibility of herbage consumed by wether sheep set-stocked on a Cheviot hill pasture. - , 1961; - - 1962; $\cdots, 1963 ;-\cdots-, 1964$.

July, and continuing to decline throughout the summer until the end of the pasture growing season. From October onwards the quality of ingested material 
falls rapidly, giving organic matter digestibilities of around $5^{\circ}$ in January and $4^{8}$ in February. Variation between years is relatively small in this part of the cycle, but the rapid increase in pasture quality following the initiation of grass growth in the spring is highly variable between years and is dependent on soil temperature.

Energy intakes are closely related to the quality of the material ingested (Blaxter, Wainman \& Wilson, I96I) and, although not measured direct in the above study, are likely to range from submaintenance levels during November to March, with a minimum of $350-45^{\circ} \mathrm{g}$ digestible organic matter per $\mathrm{d}$, to maximum values in May of about $1250 \mathrm{~g}$ digestible organic matter per $\mathrm{d}$ for wethers and $1500-1600 \mathrm{~g}$ digestible organic matter per $\mathrm{d}$ for lactating ewes. These values are low in relation to normal low-ground standards, but recent studies (Eadie, 1970) have shown that increases in the low stocking rates operating in free-grazing systems would depress minimum energy intakes in winter to even lower and quite unacceptable levels.

\section{Seasonal changes in ewe live weight and body composition}

Seasonal changes in pasture quality and hence in energy intake are to some extent a result of the intensity, or rather the lack of intensity, of grazing by the sheep stock, but these also have a profound effect on the sheep stock. Mean ewe live weights throughout the year are illustrated in Fig. 2. Live weights are at a maximum for only a short time, generally in late October, and begin to decline before mating in late November or early December. Losses continue during most of pregnancy

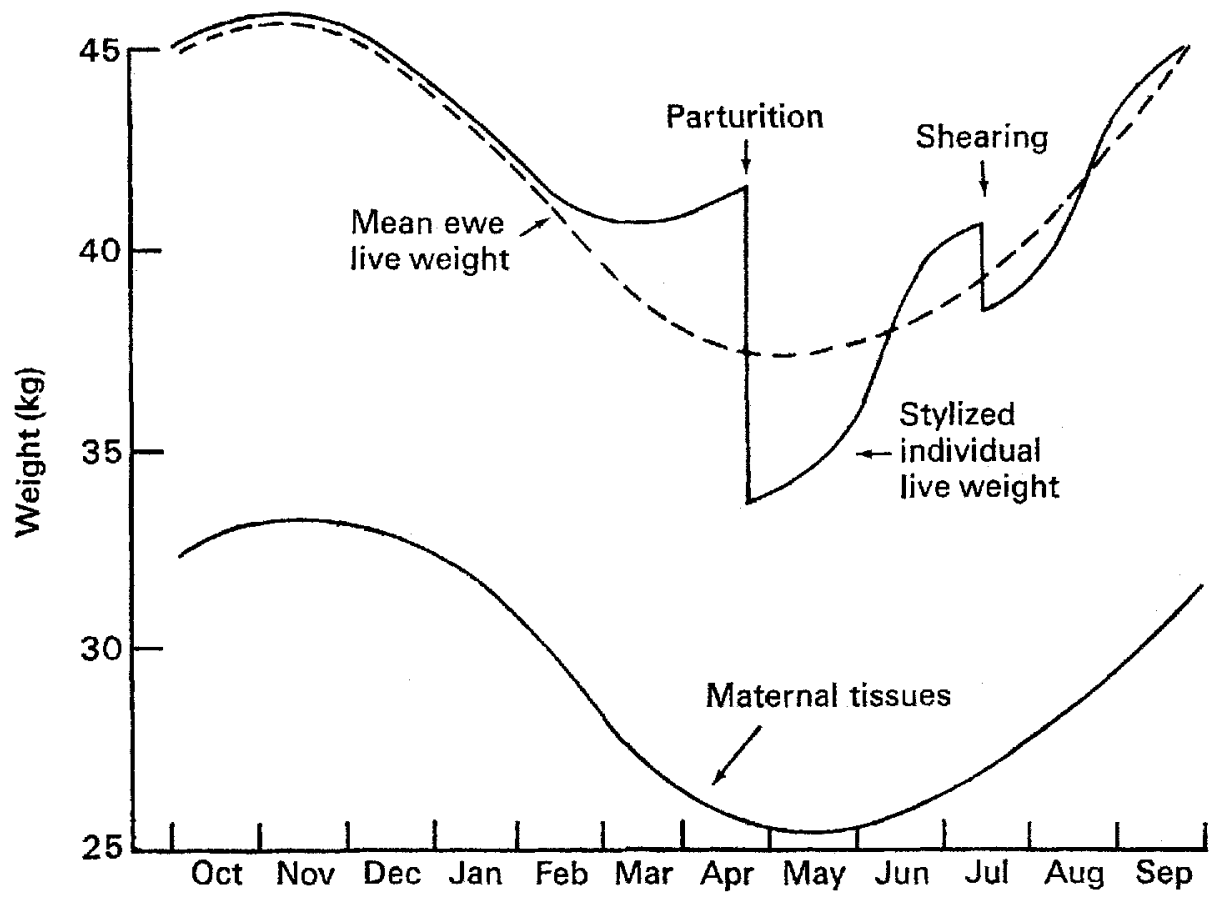

Fig. 2. Curve of mean ewe live weight and stylized curves illustrating changes in individual live weight and in the weight of maternal tissues during the year (see Russel, Gunn \& Doney, 1968). 
although there is usually a slight increase in weight during the final month as a result of foetal growth. Lambing is normally spread over a period of some weeks, and mean live weights based on varying proportions of pregnant and post-parturient ewes tend to seriously underestimate the full extent of the weight loss of individual animals from before mating until after lambing (see Fig. 2).

Changes in the body composition of ewes throughout the year are more important, and biologically more meaningful, than changes in live weight. In one study (Russel, Gunn \& Doney, 1968), conducted on a traditionally-managed non-experimental hill flock, more than $20 \%$ of the weight of maternal tissues (i.e. live weight less the weights of the fleece and the gastro-intestinal and uterine contents) was lost during pregnancy. This comprised more than $50 \%$ of the fat and about $20 \%$ of the total body protein present at maximum live weight. Changes of this magnitude are not unique to hill ewes, nor are they particularly important in themselves; what is important is the low range of body fatness over which these changes take place. In the particular study referred to, only $3 \mathrm{~kg}$ of ether-extractable material (representing some $7 \%$ of live weight) remained in the body I week before parturition. These very meagre reserves are generally depleted further during the early weeks of lactation. It is noteworthy that incidences of ewe mortality are greatest during those months when fat reserves are least (Gunn, 1967).

\section{Relationships between energy intake and some components of individual animal performance}

Fertility. Hill ewes are generally mated when in only very moderate body condition, and at a time when energy intakes are at submaintenance level and declining. Work by Wallace (196r), Coop (1962, r 1966) and others indicates that these constitute probably the worst possible combination of factors for satisfactory reproductive performance. Preliminary experiments with hill ewes showed that liberal supplementary feeding before and during mating increased lambing percentage substantially, although it was not possible to distinguish between the effects of improved body condition resulting from the feeding, and of the level of nutrition per se.

A more recent experiment (Gunn, Doney \& Russel, 1969) demonstrated that body condition at mating had a significant and positive effect on both ovulation rate and lambing percentage. Mature ewes in good body condition (approximately $29 \%$ chemical fat in the fleece-free empty body) had an ovulation percentage of 207 and a lambing percentage of 175 ; corresponding figures for ewes in poor condition (approximately $I 6 \%$ fat) were $1 \times 5$ and 94 - a level of performance typical of many hill ewe flocks. The level of energy intake before and during mating had no effect on the reproductive performance of ewes in good body condition, but there was an indication of a positive nutritional affect in the ewes in poorer condition. These results provide a measure of the response in fertility to levels of energy intake which enable the ewe to attain an improved body condition by mating time.

Lamb production. Energy requirements of ewes are high during late pregnancy. 
From the results of Russel, Doney \& Reid (1967b) it can be calculated that immediately before parturition a ewe carrying an average-sized single foetus will require twice as much energy as a non-pregnant ewe to prevent catabolism of maternal tissues; a ewe with twin foetuses will require about $2 \cdot 5$ times the energy of a ewe with none. These high levels of energy requirement exist only for a relatively short time, but in the hill environment they are seldom if ever met in full, and the ewes are consequently undernourished, sometimes to severe degrees.

The principal consequence of undernourishment during late pregnancy is a reduction in lamb birth weight. Results from the work of Russel, Doney \& Reid $(1967 a)$ indicate that the moderate degree of undernourishment (plasma non-esterified fatty acid concentrations of $700-800 \mu$ equiv./1) occurring in hill ewes with single foetuses will reduce lamb birth weight by about $10 \%$. It is unlikely that a reduction of this order in the birth weight of a single lamb will have sufficient effect on lamb survival and subsequent growth rate to justify the input of supplementary feeding required to prevent it. In twin-bearing ewes, however, the degree of undernourishment is more severe (plasma ketone concentrations of 8-10 $\mathrm{mg} / 100 \mathrm{ml}$ ) and is likely to lower birth weights by some $25 \%$, an effect which will certainly prejudice the survival of twin lambs born in a typically cold and wet hill environment.

Lactation and lamb growth. Under traditional systems of hill pasture management, milk yields in early lactation are of the order of I kg per d. Peart (1967) has shown that, with high levels of energy intake, yields of $2 \mathrm{~kg}$ milk per $\mathrm{d}$ from single-suckling ewes, and of $3 \mathrm{~kg}$ per $\mathrm{d}$ from ewes suckling twins, can be readily achieved.

Similarly, typical lamb growth rates under traditional management systems average about 2 IO $g$ per head per $d$ in single lambs until about 6 weeks of age, after which the rate of gain generally declines. Growth rates in twins are substantially poorer, and for this reason twin lambs are generally removed from hill pastures to improved grazings whenever possible. Under experimental conditions, however, where high levels of energy are available to both ewes and lambs, growth rates of $300 \mathrm{~g}$ per d to 4 weeks of age, and of more than $400 \mathrm{~g}$ from 4 to 12 weeks old are commonplace in both single and twin lambs.

It is also clear (Peart, 1967) that a less than optimum level of energy intake during late pregnancy is not incompatible with a high level of subsequent milk production, provided that the level of energy intake during lactation is correspondingly high.

In an experiment conducted in the hill environment, Eadie (unpublished) compared ewe milk yields, lamb growth rates and changes in ewe body-weight measured over the first 9 weeks of lactation in animals grazing an area of typical bent-fescue pasture, with results obtained from animals on a reseeded pasture. The responses, in milk yield and ewe body-weight change, to increased energy intakes associated with a modest improvement in herbage quality (4-5 digestibility units) are illustrated in Fig. 3. Ewes rearing single lambs produced on average $20 \%$ more milk on the better quality pasture, and their lambs gained $20 \%$ faster than those on the hill pasture; ewes suckling twins on the reseeded pasture produced on average $75 \%$ more milk and their lambs gained $40 \%$ more weight. Responses of this order represent the difference between the ability to nourish and grow twin lambs satis- 


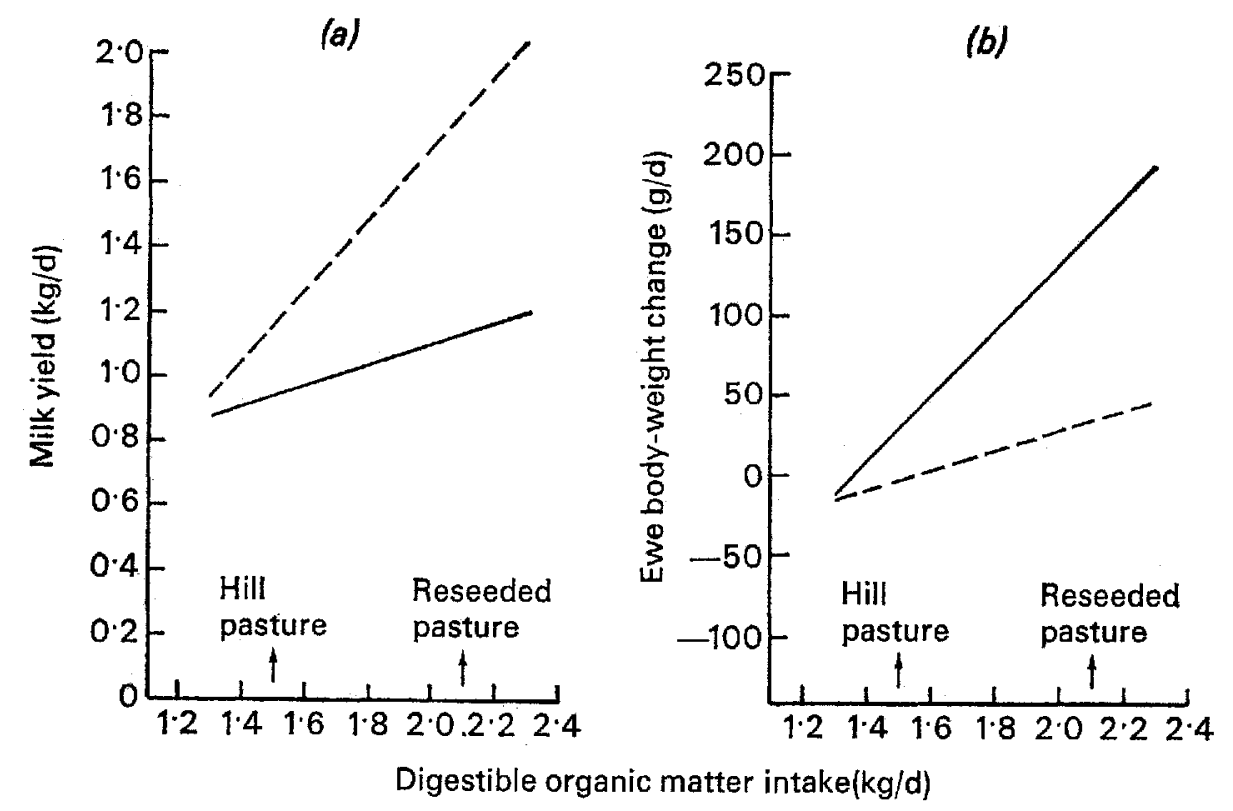

Fig. 3. Responses in a, milk yield and $b$, ewe body-weight change to increases in energy intake associated with improved pasture quality. - , ewes suckling single lambs; --, ewes suckling twin lambs.

factorily and failure to do so; in general, they illustrate the magnitude of the increase in animal production which can be achieved from a relatively small improvement in herbage quality leading to substantially increased energy intakes.

Another important response to the increased energy intakes of animals on the higher quality pasture in this experiment was an improved rate of live-weight gain in the ewes, particularly in those suckling single lambs (Fig. 3). Recovery during lactation of the weight lost during pregnancy is essential if ewes are to achieve the desired level of body condition required in the autumn for satisfactory ovulation rates and the conception of twin lambs.

Nutritional limitation to production. The relationships between energy intake and the components of individual animal productivity briefly outlined above show clearly that existing breeds of hill sheep are producing at a level considerably below their potential. It is clear that performance is limited by the level of energy intake afforded by the traditional system of management based on free-grazing, and with stocking rates determined by winter-carrying capacity. As long as energy intake remains the principal limiting factor, and until such time as the level of production more closely approaches the genetic potential of those breeds, it is unlikely that the introduction of other genotypes will increase productivity from hill land.

\section{Requirements for increased animal production}

In most hill sheep enterprises future economic progress is more likely to be achieved through increased output than by reduced costs. Realistic increases in productivity 
must include a large element of improved individual animal performance, and examination of the relationships between nutrition and the components of individual animal performance indicates that substantial increases in productivity are possible. These increases are largely dependent on improved energy intake, particularly at times of the year which have previously been regarded as unimportant.

In traditional free-grazing systems stocking rate is, and must be, determined by winter carrying capacity; winter nutrition has long been considered the principal limiting factor, and too often there has been difficulty in looking beyond this period. In any new system of management, the first requirement is for an improved level of energy intake during the summer. Under existing systems ewes increase in live weight despite, and not because of, pasture quality; an improvement in the quality of summer pasture, or at least a means of postponing the decline in digestibility, will enable ewes to achieve the better body condition required for higher conception rates. An increase in energy intake at this time will also serve to delay the onset of the decline in body-weight, which at present occurs at the beginning of pregnancy, and will provide the ewe with greater reserves on which to draw during pregnancy. Given improved body reserves, there will be little need for substantially improved levels of nutrition during December, January or most of February, but in the later stages of pregnancy, when foetal requirements increase rapidly, levels of energy intake from grazing will require to be supplemented if the ewe is to produce viable twin lambs.

Improved levels of energy intake in late summer, autumn and late winter can substantially increase the number and birth weight of lambs produced, but this will be largely a waste of expensive resources unless early spring and summer nutrition can support high levels of lactation and high growth rates in weaned lambs. Current work in the Hill Farming Research Organisation indicates that the required improvements in energy intake in spring, summer and autumn can be achieved in new systems of management based on controlled grazing.

It must be emphasized that changes in energy intake at one time of year have repercussions on productivity at other times. If attempts are made to improve the standard of nutrition at only one point in the annual cycle there is a real danger of creating problems at some later stage. Animal production is influenced by energy intake throughout the whole of the 12-month cycle, and soundly based systems aimed at increased productivity can come only from an appreciation of the importance of year-round nutrition.

\section{REFERENCES}

Blaxter, K. L., Wainman, F. W. \& Wilson, R. S. (196r). Anim. Prod. 3, 51.

Coop, I. E. (1962). N.Z. Fl agric. Res. 5, 249.

Coop, I. E. (1966). F. agric. Sci., Camb. 67, 305.

Eadie, J. (1967). Rep. Hill Fmg Res. Org. no. 4, p. 38.

Eadie, J. (1970). In Animal Populations in Relation to their Food Resources p. 7 [A. Watson, editor]. Oxford and Edinburgh: Blackwell Scientific Publications.

Gunn, R. G. (rg67). Anim. Prod. 9, 263.

Gunn, R. G., Doney, J. M. \& Russel, A. J. F. (rg69). J. agric. Sci., Camb. 73, 289.

Peart, J. N. (1967). F. agric. Sci., Camb. 68, 365.

Russel, A. J. F., Doney, J. M. \& Reid, R. L. (rg67a). 7. agric. Sci., Camb, 68, 35I. 
Russel, A. J. F., Doney, J. M. \& Reid, R. L. (1967b). Y. agric. Sci., Camb. 68, 359.

Russel, A. J. F., Gunn, R. G. \& Doney, J. M. (1968). Anim. Prod. xo, 43.

Wallace, L. R. (r96r). Proc. Ruakura Fmrs' Conf. Week p. 14.

\section{Hill pastoral resources and sheep production}

\section{By JoHn Eadie, Hill Farming Research Organisation, 29 Lauder Road, Edinburgh EH9 $2 \mathcal{Y Q}$}

Hill sheep farming in the UK takes place in a wide range of hill environments. They differ climatically, and in their soils and vegetation. Management practices vary from one hill farming region to another, as do breeds of sheep.

A major feature of hill sheep production is its low output per unit area. Output of saleable weaned lamb live weight, for example, ranges from less than $3.5 \mathrm{~kg} / \mathrm{ha}$ ( $3 \mathrm{lb} / \mathrm{acre}$ ) per annum in the poorer (but not the poorest) hill environments, to upwards of $35 \mathrm{~kg} / \mathrm{ha}$ ( $3 \circ \mathrm{lb} /$ acre) per annum in the better ones.

For many decades the low output of hill sheep farming was matched by an appropriately low-cost structure. But, since the mid 1950's costs have increased sharply due, in the main, to increases in costs of labour. Increases in costs of labour bear heavily on hill sheep production since they amount to some $30-40 \%$ of total costs. Over the same period the prices of store lambs and cast ewes have remained static. The consequence has been that, despite the changes in the value of the $f$ over that period, the net profit per farm has not improved, while government support has risen from around $60-70 \%$ to $130-190 \%$ of the net profit (Duthie, I968).

The important point for the future is that costs of labour are likely to continue to increase at a faster rate than prices. One approach to the problem would be to attempt to reduce costs; this may be possible in some instances in the short term but it will not provide a general long-term solution.

A much more meaningful approach is to attempt to develop systems of hill sheep production within which unit costs of production will be significantly reduced. Equally important is the need to do this in such a way as to provide opportunities, extending well into the future, for reacting to economic change and technical advance. This, in effect, requires the establishment of a production framework within which, in the longer if not in the short term, substantial increases in output are possible. Basic to any progress in this direction is an adequate biological understanding of the processes of production. But, biological and economic efficiencies are not necessarily coincident. It is therefore necessary to employ the consequences of that biological understanding within an economic framework with the constraints that this implies.

The low outputs of sheep products of existing systems of hill sheep production are a function of low stocking rates and of poor levels of sheep performance. Some $65 \%$ of the hill sheep in Scotland are stocked at rates of between one sheep per 0.8 